\title{
Effects of tropical climate and season on growth, chemical composition of muscle and adipose tissue and meat quality in pigs
}

\author{
Dominique RINALDO $^{\mathrm{a} *}$, Jacques MOUROT ${ }^{\mathrm{b}}$ \\ ${ }^{a}$ Institut National de la Recherche Agronomique, Unité de Recherches Zootechniques, \\ Domaine de Duclos, 97170 Petit-Bourg, Guadeloupe, FWI \\ b Institut National de la Recherche Agronomique, Unité Mixte de Recherches sur le Veau et le Porc, \\ 35590 Saint-Gilles, France
}

(Received 20 July 1999; accepted 5 November 2001)

\begin{abstract}
The effects of tropical climate and season on growth performance, meat quality and chemical composition of muscle and adipose tissue were determined on ad libitum fed Large White pigs. Individually housed animals placed in a tropical climate in a semi-open room were compared to those kept in a climatic room at constant $20^{\circ} \mathrm{C}$ and $75 \%$ relative humidity (control climate, CC). During the cool season in the tropical climate (CTC), the ambient temperature averaged $24.8 \pm 3.6^{\circ} \mathrm{C}$ and relative humidity was $83 \pm 14 \%$. Corresponding figures for the warm season in the tropical climate (WTC) were $27.9 \pm 3.0^{\circ} \mathrm{C}$ and $81 \pm 12 \%$, respectively. The voluntary feed intake (VFI) of animals reared in CTC weighing between 35 and $94 \mathrm{~kg}$ decreased by $9 \%(P<0.001)$, as compared to CC. In WTC, VFI of the 35 to $94 \mathrm{~kg}$ animals decreased by $13 \%(P<0.001)$ and average daily gain by $12 \%$ $(P<0.01)$, as compared to CC, whereas their carcasses were leaner at slaughter $(P<0.05)$. Ultimate $\mathrm{pH}$ of muscles longissimus dorsi $(P<0.01)$ and biceps femoris $(P<0.05)$ was higher in the tropical climate than in CC whereas moisture loss of the biceps femoris and semispinalis muscles was lower $(P<0.05)$. The lipid content of leaf fat declined in WTC $(P<0.05)$, as compared to CC. Exposition to the tropical climate resulted in a lower lipid content of the outer layer of backfat $(P<0.05)$ and a higher degree of unsaturation of fat in the entire backfat $(P<0.01)$, as compared to CC. Neither the chemical composition of backfat inner layer and M. longissimus dorsi nor the degree of unsaturation of lipids in the latter were significantly altered by the environment. The results suggest that tropical climate may have a favourable influence on pork quality.
\end{abstract}

growing pig / tropical environment / skeletal muscle / adipose tissue / meat quality

Résumé - Influence du climat tropical et de la saison sur la composition chimique des muscles et des tissus adipeux et la qualité de viande du porc en croissance. Un essai a été mené pour déterminer les effets du climat tropical sur les performances de croissance, la composition chimique des muscles et des tissus adipeux et la qualité de la viande de porcs Large White. Au total 40 femelles

* Correspondence and reprints

Tel.: 33 (0)5 9025 59 33; fax: 33 (0)5 9025 59 36; e-mail: rinaldo @ antilles.inra.fr 
et mâles castrés ont été nourris ad libitum et logés en cage individuelle entre 15 et $94 \mathrm{~kg}$ de poids vif. Les porcs placés en climat tropical dans une salle semi-ouverte ont été comparés aux témoins élevés dans une salle à ambiance contrôlée dans laquelle la température ambiante a été maintenue constamment à $20^{\circ} \mathrm{C}$ et l'humidité relative $(\mathrm{Hr})$ à $75 \%$. Les mesures réalisées dans la salle semi-ouverte au niveau des animaux indiquent qu'en climat tropical en saison chaude la température ambiante est en moyenne de $27,9 \pm 9,3^{\circ} \mathrm{C}$ et l' $\mathrm{Hr}$ de $81 \pm 12 \%$. Les chiffres correspondant en saison fraîche sont de $24,8 \pm 3,6{ }^{\circ} \mathrm{C}$ et de $83 \pm 14 \%$, respectivement. En saison fraîche en climat tropical le niveau d'ingestion spontané d'aliment des porcs entre 35 et $94 \mathrm{~kg}$ de poids vif décroît de $9 \%$, relativement aux témoins. Chez le porc de 35 à $94 \mathrm{~kg}$ de poids vif, une diminution de $13 \%$ de la quantité d'aliment consommé $(P<0,001)$ et de $12 \%$ du gain de poids $(P<0,01)$ est observée en saison chaude en climat tropical sans modification significative de l'indice de consommation, par rapport aux témoins. Les porcs élevés en saison chaude en climat tropical sont les plus maigres $(P<0,05)$. Le pH ultime des muscles longissimus dorsi $(P<0,01)$ et biceps femoris $(P<0,05)$ est plus élevé en climat tropical que dans une ambiance de $20{ }^{\circ} \mathrm{C}$ et $75 \%$ d'Hr alors que les pertes en eau des muscles biceps femoris et semispinalis sont plus faibles $(P<0,05)$. Les plus faibles teneurs en lipides d'un tissu adipeux interne, la panne, sont observées en climat tropical pendant la saison chaude $(P<0,05)$. Indépendamment de la saison, chez les porcs élevés en climat tropical, la teneur en lipides d'un tissu adipeux sous-cutané, la couche externe de la bardière, décroît par rapport au milieu témoin $(P<0,05)$, et le coefficient d'insaturation des lipides de la bardière entière est plus élevé $(P<0,01)$ que chez les témoins. Ni la composition chimique de la couche interne de la bardière et du muscle longissimus dorsi ni le degré d'insaturation des lipides de ce muscle ne sont significativement affectés par les conditions environnementales. Nos résultats suggèrent que le climat tropical pourrait avoir une influence favorable sur la qualité technologique et nutritionnelle de la viande de porc.

porc en croissance/ climat tropical / muscle / tissu adipeux / qualité de viande

\section{INTRODUCTION}

In the tropics, the quality of pig meat from locally reared animals is often assumed to be better than that imported from temperate areas, even when pigs are fed similar diets based on cereals. This might be attributed, at least partly, to the climate which is characterised in the Caribbean area by both high ambient temperature and relative humidity. Pork quality is well known to be highly dependent on various factors such as breed, sex, slaughter weight and feeding conditions [2, 10, 34, 37]. Studies on young $20-30 \mathrm{~kg}$ pigs have shown that a high ambient temperature in the range of $31.5-35^{\circ} \mathrm{C}$ induces a general slowing down in the metabolism of skeletal muscle and adipose tissue and modifies the chemical composition of fat $[6,27]$. A few studies have assessed the influence of constant [18] or fluctuating $[3,19]$ high ambient temperature on meat quality and the characteristics of adipose tissue and muscles of pigs slaughtered at $90-105 \mathrm{~kg}$ body weight. A constant ambient temperature of $28^{\circ} \mathrm{C}$ had favourable effects on the following characteristics, as compared to $12{ }^{\circ} \mathrm{C}$ : meat quality linked to higher ultimate $\mathrm{pH}$ in white muscle, lower lipid content of red muscle and unsaturation of lipids in backfat [18]. However, no change was observed in meat quality as assessed by colour, marbling and firmness of the M. longissimus dorsi area in ad libitum fed pigs exposed to a cycling ambient temperature of $27-35^{\circ} \mathrm{C}$ in comparison to animals housed at temperatures in the range of 18 to $21^{\circ} \mathrm{C}[3,19]$. There is also a lack of information on the influence of environmental conditions on the fatty acid composition of lipids in muscle. The effect of an actual tropical climate on meat quality has not yet been investigated. The present trial was designed to determine whether the effects of tropical climate and season on growth performance are concomitant with 
changes in the chemical composition of muscle and adipose tissue and meat quality in Large White pigs.

\section{MATERIALS AND METHODS}

This experiment was conducted in Guadeloupe (French West Indies, $16^{\circ}$ Lat. N., $61^{\circ}$ Long. W.) to establish the effects of tropical climate and season on the performance and characteristics of muscle and adipose tissue in Large White growing pigs fed ad libitum, as compared to a control environment. To do this, two climatic treatments were used: a tropical climate vs. a constant relative humidity $(\mathrm{RH})$ of $75 \%$ and air temperature of $20^{\circ} \mathrm{C}$. A temperature of $20{ }^{\circ} \mathrm{C}$ was chosen because it is within the temperature range recommended for maximum average daily gain $[11,25]$. The two climatic treatments were compared both during the cool season, from November to February, and during the warm season, from April to October.

\subsection{Experimental procedure, feeding and housing}

A total of 40 individually housed castrates and females were fed ad libitum from $14.7 \pm 1.8 \mathrm{~kg}$ live weight to slaughter at $93.5 \pm 2.5 \mathrm{~kg}$. Two commercial diets, which are the conventional diets available in Guadeloupe, were used and their chemical composition is shown in Table I. Pigs were fed diet 1 from 15 to $35 \mathrm{~kg}$ live weight and diet 2

Table I. Composition ( $\mathrm{g} \cdot \mathrm{kg}^{-1}$ diet) of the two experimental diets given to the 15 to $35 \mathrm{~kg}$ body weight (BW) pigs (diet 1) and to the 35 to $94 \mathrm{~kg} \mathrm{BW}$ pigs (diet 2).

\begin{tabular}{|c|c|c|}
\hline & Diet 1 & Diet 2 \\
\hline \multicolumn{3}{|l|}{ Measured by chemical analysis: } \\
\hline Dry matter & 885 & 881 \\
\hline Crude protein & 186 & 168 \\
\hline NDF & 98 & 127 \\
\hline $\mathrm{ADF}$ & 31 & 40 \\
\hline Crude fat & 39 & 39 \\
\hline \multicolumn{3}{|l|}{ Fatty acids: } \\
\hline $\mathrm{C} 14: 0$ & 0.6 & 0.1 \\
\hline C16:0 & 7.6 & 6.8 \\
\hline $\mathrm{C} 16: 1$ & 0.5 & 0.3 \\
\hline C18:0 & 1.6 & 1.2 \\
\hline C18:1 & 8.3 & 9.0 \\
\hline C18:2 & 18.5 & 19.9 \\
\hline $\mathrm{C} 18: 3$ & 1.5 & 1.4 \\
\hline $\mathrm{C} 20: 0$ & - & - \\
\hline C20:1 & 0.8 & - \\
\hline \multicolumn{3}{|l|}{ Assessed by calculation ${ }^{1}$ : } \\
\hline Lysine & 11.4 & 8.5 \\
\hline Methione + cystine & 7.0 & 5.7 \\
\hline Threonine & 7.3 & 6.0 \\
\hline Tryptophan & 2.4 & 1.9 \\
\hline Metabolisable energy $\left(\mathrm{MJ} \cdot \mathrm{kg}^{-1}\right)$ & 13.26 & 12.74 \\
\hline
\end{tabular}

${ }^{1}$ Calculations were made on the basis of the composition of the ingredients of the feed. 
from $35 \mathrm{~kg}$ to slaughter. The metabolisable energy (ME) and crude protein contents of diet 1 were respectively $13.3 \mathrm{MJ} \cdot \mathrm{kg}^{-1}$ and $18.6 \%$ and diet 2 provided $12.7 \mathrm{MJ} \mathrm{ME} \cdot \mathrm{kg}^{-1}$ and $16.8 \%$ of crude protein. The pigs had free access to water using a nipple water drinker. For each of the two seasons, five litters were weaned simultaneously at $28 \pm 2 \mathrm{~d}$ of age. Within each litter, four animals, two castrates and two females, were chosen and entered the experimental building. One castrate and one female per litter were placed in a tropical climate and the other two littermates in a climatic room at $20^{\circ} \mathrm{C}, 75 \% \mathrm{RH}$ until slaughter. Pigs were assigned to one of the two climatic treatments to get a complete balanced block design, according to litter origin, sex and live weight.

The animals reared under the tropical climate were placed in a semi-open room in which the air temperature and RH were continuously recorded using probes located at the level of the pigs. On the day the control animals entered the climatic room, the air temperature was set at $28{ }^{\circ} \mathrm{C}$ and $\mathrm{RH}$ at $75 \%$. The $\mathrm{RH}$ remained unchanged until the end of the trial whereas air temperature was gradually reduced to $20^{\circ} \mathrm{C}$ by the 9 th day postweaning and remained constant thereafter. The trial began 5 d later. In the climatic room, which has previously been described by Rinaldo et al. [29], ambient temperature and $\mathrm{RH}$ were controlled and regulated within $\pm 0.5^{\circ} \mathrm{C}$ and $\pm 3 \%$, respectively. The individually penned animals were placed in wired cages with metal slatted floors.

\subsection{Measurements and analyses}

\subsubsection{Performance and carcass traits}

The animals were weighed and their voluntary feed intake was determined weekly during the whole experiment. When they reached $93.5 \pm 2.5 \mathrm{~kg}$ live weight, the pigs were slaughtered after an overnight fast. The animals were weighed, stunned, exsanguinated and eviscerated. The weights of the full and emptied digestive tracts were recorded to calculate the empty body weight. After $24 \mathrm{~h}$ chilling at $4{ }^{\circ} \mathrm{C}$, the carcasses were split into halves which were weighed. The left half-carcass was measured for average backfat thickness as a mean of first rib, last rib and last lumbar vertebrae values. This half-carcass was cut into pieces according to the method described by Ollivier [26]. Fat and muscle percentages were assessed from the weights of the left half-carcass and those of fat and lean cuts by using the predicting equation established by Desmoulin et al. [8]. The validity of this equation in the present experimental conditions was checked by comparing the actual fat and muscle percentages measured using the weights of tissues obtained by dissection of the carcasses with those assessed using the equation. This comparison was carried out during the warm season on a total of 12 pigs, half of which were housed in the control room and the others in the tropical climate. Whatever the climatic treatment, no significant difference was found between the actual and assessed fat and muscle percentages. The equation found by Desmoulin et al. [8] was thus considered as valid in tropical conditions and used to determine the carcass traits of the pigs.

\subsubsection{Feed analyses}

Feed samples were pooled weekly and analysed for dry matter content. Their protein content was estimated from nitrogen $(\mathrm{N} \times 6.25)$ measured by the Kjeldahl method. Neutral Detergent Fibre (NDF) and Acid Detergent Fibre (ADF) contents were determined according to Van Soest et al. [35]. Total lipids were extracted according to Folch et al. [12]. Fatty acid methyl esters were prepared with boron fluoride methanol according to Morrison and Smith [22] and analysed on a Di 200 gas chromatograph (Delsi, Paris, France) (capillary column CW $20 \mathrm{M}$, temperature: $180^{\circ} \mathrm{C}$, hydrogen pressure: 0.5 bar), using margaric acid as an 
internal standard. The oven, detector and injector temperatures were maintained at 180,240 and $220^{\circ} \mathrm{C}$, respectively. Retention time and peak areas were determined using ordinat software (Nelson Analytical, Inc., San Jose, USA).

\subsubsection{Meat quality and measurements on muscle and adipose tissue}

Meat quality criteria and chemical composition of muscle and adipose tissue were determined on a total of 32 animals, i.e. 8 pigs per climatic treatment within each of the two seasons.

Meat quality criteria were determined on the following three muscles: M. semispinalis, M. longissimus dorsi at the last rib level and M. biceps femoris. The $\mathrm{pH}$ was measured at $45 \mathrm{~min}(\mathrm{pH} 1)$ and $24 \mathrm{~h}(\mathrm{pH} 2)$ post mortem using a $\mathrm{pH}$ meter probe. The water-holding capacity of muscles was determined using the filter paper press method described by Goutefongea [14] and modified by Lefaucheur et al. [18].

Immediately after slaughter, samples of about $10 \mathrm{~g}$ of the following adipose tissues were taken on the right half-carcass: leaf fat, outer and inner layers of subcutaneous backfat at the neck level. Samples of about $60 \mathrm{~g}$ of M. semispinalis and M. longissimus dorsi at the last rib level were also taken within 20 min after exsanguination. The tissues were cleaned up. The whole muscle sample and half the sample of adipose tissue were freeze-dried while the remaining adipose tissue was frozen $\left(-18{ }^{\circ} \mathrm{C}\right)$. The dry matter and crude protein $(\mathrm{N} \times 6.25)$ contents of muscle and adipose tissue were measured on freeze-dried samples. Frozen samples of adipose tissue and freeze-dried samples of muscle were analysed for their fat content and the fatty acid composition of their lipids as previously described for feed. The unsaturation coefficient of lipids was calculated according to Courboulay and Mourot [7].

\subsubsection{Statistical analyses}

Statistical analyses were carried out by analysis of variance using the general linear model (G.L.M.) procedure of the Statistical Analysis System (S.A.S., 1994) [30]. The effects of climatic treatment, season, sex, the interaction between climatic treatment and season, the interaction between sex and climatic treatment and the interaction between climatic treatment $\times$ season $\times$ sex were assessed. After making sure that the data obtained for the control treatment did not significantly differ from one season to the other, the data were pooled. There were therefore three environments, either the control treatment, or the cool or warm season in the tropical climate. The adjusted means presented in the tables were calculated by assessing the effects of the environment, sex and the interaction between the environment and sex.

\section{RESULTS}

\subsection{Climatic parameters}

Under tropical climate, the average ambient temperature measured at the level of the animals was $27.9 \pm 3.0^{\circ} \mathrm{C}$ during the warm season and $24.8 \pm 3.6{ }^{\circ} \mathrm{C}$ during the cool one. The corresponding figures for RH were $81 \pm 12 \%$ and $83 \pm 14 \%$, respectively. According to present data, diurnal variations in both ambient temperature and $\mathrm{RH}$ were more marked than seasonal changes. The difference between minimal nocturnal temperature and maximal diurnal temperature was about $6{ }^{\circ} \mathrm{C}$ with little variation over the year. Maximal RH was on the average $95 \pm 3 \%$ during the night time and mean minimal RH was $72 \pm 9 \%$ around midday. Recorded data showed that in the climatic room average ambient temperature was 20.0 $\pm 0.5^{\circ} \mathrm{C}$ and $\mathrm{RH}$ was $75 \pm 4 \%$.

\subsection{Growth and carcass traits}

During the cool season, the tropical climate had no significant effect on the growth 
response in 15 to $35 \mathrm{~kg}$ pigs, as compared to the control environment (Tab. II). In 35 to $94 \mathrm{~kg}$ pigs, the voluntary feed intake (VFI) was $9 \%$ lower $(P<0.01)$ in animals reared in the cool season in the tropical climate than in the control pigs and their backfat was thinner $(P<0.05)$. During the warm season in the tropical climate, a $6 \%$ decrease in VFI $(P<0.05)$ was observed in $15-35 \mathrm{~kg}$ pigs without any change in their average daily gain due to a 0.11 unit improvement in the feed to gain ratio $(P<0.01)$, as compared to the control environment. In heavier pigs, a $13 \%$ decline in VFI $(P<0.001)$ during the warm season led to a $12 \%$ drop in the average daily gain $(P<0.01)$ whereas feed to gain ratio was not significantly altered, as compared to the control environment. Within the tropical climate, during the warm season, there was a $9 \%$ reduction in the average daily gain in animals between 35 and $90 \mathrm{~kg}$, as compared to the cool season $(P<0.01)$.

Whatever the season, average backfat thickness was lower in the tropical climate than in the control environment $(P<0.05)$. The environmental conditions had no significant effect on muscle percentage, whereas fat percentage of pigs raised in a tropical climate during the warm season was lower than that of animals reared during the cool one $(P<0.05$, Tab. II).

Between 35 and $90 \mathrm{~kg}$ live weight, castrates ate $11 \%(P<0.001)$ more food, had a $7 \%(P<0.05)$ higher average daily gain and were fatter at slaughter $(P<0.05)$ than females (Tab. II). No interactions between environment and sex were observed in growth performance and carcass traits.

Table II. The effect of the tropical climate and season on performance and carcass traits of ad libitum fed growing pigs in relation to the live weight.

\begin{tabular}{|c|c|c|c|c|c|c|c|c|}
\hline & \multicolumn{3}{|c|}{ Environment } & \multirow{2}{*}{\multicolumn{2}{|c|}{ Sex }} & \multirow[b]{3}{*}{ R.S.D. } & \multirow{2}{*}{\multicolumn{2}{|c|}{$\begin{array}{l}\text { Signifi- } \\
\text { cance }^{1}\end{array}$}} \\
\hline & \multirow{2}{*}{$\begin{array}{c}\text { Control } \\
\\
20{ }^{\circ} \mathrm{C}, \\
75 \% \mathrm{RH}\end{array}$} & \multicolumn{2}{|c|}{ Tropical climate } & & & & & \\
\hline & & $\begin{array}{c}\text { Cool season } \\
24.8 \pm 3.6^{\circ} \mathrm{C}\end{array}$ & $\begin{array}{l}\text { Warm season } \\
27.9 \pm 3.0^{\circ} \mathrm{C}\end{array}$ & females & castrates & & E & Sex \\
\hline Number of pigs & 20 & 10 & 10 & 20 & 20 & & & \\
\hline Initial weight (kg) & 14.6 & 14.0 & 14.9 & 14.2 & 14.6 & 1.8 & $\mathrm{~ns}$ & $\mathrm{~ns}$ \\
\hline Final weight $(\mathrm{kg})$ & 93.2 & 93.6 & 94.3 & 93.4 & 93.7 & 2.5 & $\mathrm{~ns}$ & $\mathrm{~ns}$ \\
\hline \multicolumn{9}{|l|}{15 to $35 \mathrm{~kg}$ period } \\
\hline Feed intake $\left(\mathrm{g} \cdot \mathrm{d}^{-1}\right)$ & $1281^{\mathrm{a}}$ & $1239^{\mathrm{ab}}$ & $1206^{\mathrm{b}}$ & 1182 & 1302 & 112 & * & $* *$ \\
\hline Average daily gain (g) & 752 & 759 & 757 & 733 & 779 & 60 & $\mathrm{~ns}$ & $*$ \\
\hline Feed:gain ratio & $1.70^{\mathrm{a}}$ & $1.63^{\mathrm{ab}}$ & $1.59^{\mathrm{b}}$ & 1.61 & 1.66 & 0.12 & $* *$ & ns \\
\hline \multicolumn{9}{|l|}{35 to $90 \mathrm{~kg}$ period } \\
\hline Feed intake $\left(\mathrm{g} \cdot \mathrm{d}^{-1}\right)$ & $2301^{\mathrm{a}}$ & $2101^{b}$ & $2001^{b}$ & 2028 & 2254 & 93 & $* * *$ & $* * *$ \\
\hline Average daily gain (g) & $910^{\mathrm{a}}$ & $883^{\mathrm{a}}$ & $802^{b}$ & 839 & 901 & 64 & $* *$ & $*$ \\
\hline Feed:gain ratio & 2.53 & 2.38 & 2.50 & 2.42 & 2.50 & 0.15 & ns & ns \\
\hline Average backfat $(\mathrm{cm})$ & $2.24^{\mathrm{a}}$ & $2.06^{\mathrm{b}}$ & $2.05^{\mathrm{b}}$ & 1.93 & 2.28 & 0.14 & * & * \\
\hline Muscle (\%) & 55.0 & 54.1 & 54.2 & 55.5 & 53.3 & 2.0 & $\mathrm{~ns}$ & * \\
\hline Fat $(\%)$ & $21.4^{\mathrm{ab}}$ & $22.6^{\mathrm{a}}$ & $20.1^{\mathrm{b}}$ & 20.4 & 22.9 & 2.4 & * & * \\
\hline
\end{tabular}

E: effect of environment.

1 ns: not significant; $* P<0.05 ; * * P<0.01 ; * * * P<0.001$

a, b Means that do not have a common superscript letter differ significantly. 


\subsection{Meat quality, muscle and adipose tissue composition}

The present results indicate no significant influence of sex on the chemical composition of adipose tissue and muscle, fatty acid composition of lipids and meat quality. Only pooled data for sex are therefore presented.

\subsubsection{Adipose tissue}

The lipid content of the entire backfat was lower than that of leaf fat $(78.9 \pm 0.5 \%$ and $83.6 \pm 0.8 \%$, respectively, $P<0.001)$ irrespective of the environment, whereas protein content was higher $(3.9 \pm 0.2 \%$ and $2.2 \pm 0.2 \%$, respectively, $P<0.001)$. Backfat outer layer was poorer in lipids than the inner layer in the tropical climate $(75.6 \pm 0.8 \%$ and $78.2 \pm 0.5 \%$, respectively, $P<0.05)$ whereas the lipid contents of the two layers were similar in the control environment. A reduction in the lipid content of the outer layer of backfat $(P<0.05)$ was observed in the tropical climate during both seasons, as compared to the control environment (Tab. III). Tropical climate not only modified the amount of lipids deposited in backfat but also influenced their fatty acid composition (Tab. IV). The unsaturation coefficient of lipids in backfat in both layers was higher in the tropical climate than in the control environment $(P<0.01)$. However, only polyunsaturated fatty acids (C18:2 and C18:3) were

Table III. The effect of the tropical climate and season on the chemical composition of subcutaneous and leaf adipose tissues in growing pigs slaughtered at $90 \mathrm{~kg}$ live weight.

\begin{tabular}{|c|c|c|c|c|c|}
\hline \multirow[b]{3}{*}{$\begin{array}{l}\text { Chemical } \\
\text { composition }(\%)\end{array}$} & \multicolumn{3}{|c|}{ Environment } & \multirow[b]{3}{*}{ R.S.D. } & \multirow{3}{*}{$\begin{array}{c}\text { Significance }^{1} \\
\text { E }\end{array}$} \\
\hline & \multirow{2}{*}{$\begin{array}{l}\text { Control } \\
20{ }^{\circ} \mathrm{C} \text {, } \\
75 \% \mathrm{RH}\end{array}$} & \multicolumn{2}{|c|}{ Tropical climate } & & \\
\hline & & $\begin{array}{l}\text { Cool season } \\
24.8 \pm 3.6^{\circ} \mathrm{C}\end{array}$ & $\begin{array}{l}\text { Warm season } \\
27.9 \pm 3.0^{\circ} \mathrm{C}\end{array}$ & & \\
\hline \multicolumn{6}{|l|}{ Entire backfat } \\
\hline Dry matter & 86.8 & 88.1 & 85.9 & 3.3 & ns \\
\hline Lipid & 78.8 & 78.1 & 79.9 & 2.5 & ns \\
\hline Protein & 4.1 & 3.6 & 3.9 & 1.1 & ns \\
\hline \multicolumn{6}{|c|}{ Backfat outer layer } \\
\hline Dry matter & 88.7 & 86.6 & 86.0 & 1.9 & ns \\
\hline Lipid & $80.6^{\mathrm{a}}$ & $76.0^{\mathrm{b}}$ & $75.1^{\mathrm{b}}$ & 2.5 & $*$ \\
\hline Protein & 4.0 & 3.8 & 3.8 & 0.5 & ns \\
\hline \multicolumn{6}{|c|}{ Backfat inner layer } \\
\hline Dry matter & 88.8 & 89.4 & 89.5 & 1.4 & ns \\
\hline Lipid & 78.8 & 78.2 & 78.1 & 1.7 & ns \\
\hline Protein & 3.2 & 3.4 & 3.4 & 0.4 & ns \\
\hline \multicolumn{6}{|l|}{ Leaf fat } \\
\hline Dry matter & $88.3^{\mathrm{b}}$ & $92.0^{\mathrm{a}}$ & $86.9^{\mathrm{b}}$ & 3.3 & $*$ \\
\hline Lipid & $84.6^{\mathrm{a}}$ & $86.6^{\mathrm{a}}$ & $79.6^{\mathrm{b}}$ & 4.0 & $*$ \\
\hline Protein & 2.3 & 1.7 & 2.6 & 0.8 & ns \\
\hline
\end{tabular}

E: effect of environment.

${ }^{1}$ ns: not significant; $* P<0.05$.

a, b Means that do not have a common superscript letter differ significantly. 
increased in the tropical climate as compared to the control environment $(P<0.05)$, whereas monounsaturated fatty acids $(\mathrm{C} 18: 1$ and C20:1) were reduced $(P<0.05)$.
In the tropical climate, there was a 5.1 percentage units $(P<0.05)$ decline in the dry matter content of leaf fat and a 7.0 percentage units $(P<0.05)$ decrease in its lipid content

Table IV. The effect of the tropical climate and season on the fatty acid composition of lipids in subcutaneous and leaf adipose tissues (as \% total fatty acids) in growing pigs slaughtered at $90 \mathrm{~kg}$ live weight.

\begin{tabular}{|c|c|c|c|c|c|}
\hline \multirow[b]{3}{*}{$\begin{array}{l}\text { Fatty acids } \\
(\%)\end{array}$} & \multicolumn{3}{|c|}{ Environment } & \multirow[b]{3}{*}{ R.S.D. } & \multirow{3}{*}{$\begin{array}{c}\text { Significance }^{1} \\
\text { E }\end{array}$} \\
\hline & \multirow{2}{*}{$\begin{array}{l}\text { Control } \\
20{ }^{\circ} \mathrm{C}, \\
75 \% \mathrm{RH}\end{array}$} & \multicolumn{2}{|c|}{ Tropical climate } & & \\
\hline & & $\begin{array}{l}\text { Cool season } \\
24.8 \pm 3.6^{\circ} \mathrm{C}\end{array}$ & $\begin{array}{l}\text { Warm season } \\
27.9 \pm 3.0^{\circ} \mathrm{C}\end{array}$ & & \\
\hline \multicolumn{6}{|l|}{ Backfat } \\
\hline C14:0 & 1.2 & 1.3 & 1.3 & 0.2 & ns \\
\hline C16:0 & 24.4 & 24.4 & 24.1 & 0.9 & ns \\
\hline C16:1 & 2.1 & 1.9 & 2.2 & 0.4 & ns \\
\hline C18:0 & 12.8 & 13.4 & 12.0 & 1.5 & ns \\
\hline C18:1 & $41.1^{\mathrm{a}}$ & $37.3^{\mathrm{b}}$ & $39.2^{\mathrm{ab}}$ & 1.9 & $* *$ \\
\hline C18:2 & $16.8^{\mathrm{a}}$ & $19.9^{\mathrm{b}}$ & $19.5^{\mathrm{b}}$ & 2.6 & $*$ \\
\hline C18:3 & $0.85^{\mathrm{a}}$ & $1.17^{\mathrm{b}}$ & $1.02^{\mathrm{ab}}$ & 0.18 & $*$ \\
\hline C20:0 & 0.13 & 0.12 & 0.22 & 0.10 & ns \\
\hline C20:1 & $0.62^{\mathrm{a}}$ & $0.51^{\mathrm{ab}}$ & $0.46^{\mathrm{b}}$ & 0.11 & $*$ \\
\hline$\sum$ monounsaturated & $43.8^{\mathrm{a}}$ & $39.7^{\mathrm{b}}$ & $41.9^{a b}$ & 2.2 & $* *$ \\
\hline $\begin{array}{l}\sum \text { polyunsaturated } \\
\text { Unsaturation }\end{array}$ & $17.7^{\mathrm{a}}$ & $21.1^{\mathrm{b}}$ & $20.5^{\mathrm{ab}}$ & 2.8 & $*$ \\
\hline coefficient $^{2}(\%)$ & $1.30^{\mathrm{a}}$ & $1.35^{\mathrm{b}}$ & $1.37^{\mathrm{b}}$ & 0.04 & $* *$ \\
\hline $\mathrm{P} / \mathrm{S}^{3}$ & $0.46^{\mathrm{a}}$ & $0.54^{\mathrm{b}}$ & $0.55^{\mathrm{b}}$ & 0.08 & $*$ \\
\hline \multicolumn{6}{|l|}{ Leaf fat } \\
\hline C14:0 & 1.4 & 1.4 & 1.5 & 0.1 & ns \\
\hline C16:0 & 28.0 & 27.8 & 28.0 & 1.3 & ns \\
\hline C16:1 & 1.7 & 1.7 & 1.7 & 0.3 & ns \\
\hline C18:0 & 19.5 & 19.2 & 19.4 & 1.7 & ns \\
\hline C18:1 & 34.8 & 33.5 & 34.0 & 2.7 & ns \\
\hline C18:2 & 13.3 & 14.9 & 14.0 & 3.3 & ns \\
\hline C18:3 & $0.65^{\mathrm{a}}$ & $0.90^{\mathrm{b}}$ & $0.79^{a b}$ & 0.18 & $* *$ \\
\hline C20:0 & 0.20 & 0.17 & 0.18 & 0.04 & ns \\
\hline C20:1 & 0.45 & 0.43 & 0.43 & 0.07 & ns \\
\hline$\sum$ monounsaturated & 37.0 & 35.6 & 36.1 & 2.9 & ns \\
\hline $\begin{array}{l}\sum_{\text {Unsaturation }} \text { polyunsaturated } \\
\text { Undion }\end{array}$ & 13.9 & 15.8 & 14.7 & 3.5 & ns \\
\hline coefficient $^{2}(\%)$ & 1.30 & 1.33 & 1.31 & 0.06 & ns \\
\hline $\mathrm{P} / \mathrm{S}^{3}$ & 0.30 & 0.33 & 0.30 & 0.08 & ns \\
\hline
\end{tabular}

E: effect of environment.

${ }^{1}$ ns: not significant; $* P<0.05 ; * * P<0.01$

a, b Means that do not have a common superscript letter differ significantly.

2 The unsaturation coefficient (UC) was calculated as follows:

$\mathrm{UC}=((\% \mathrm{C} 16: 1+\% \mathrm{C} 18: 1) * 1+(\% \mathrm{C} 18: 2 * 2)+(\mathrm{C} 18: 3 * 3)) /(\mathrm{C} 16: 1+\mathrm{C} 18: 1+\mathrm{C} 18: 2+\mathrm{C} 18: 3)$

${ }^{3} \mathrm{P} / \mathrm{S}=\frac{\sum \text { polyunsaturated fatty acids }}{\sum \text { saturated fatty acids }}$. 
during the warm season, as compared to the cool period of the year (Tab. III). The environment had very little influence on the fatty acid composition of the lipids in leaf fat (Tab. IV).

\subsubsection{Meat quality criteria}

pH1 in the muscles was not significantly influenced by the environment (Tab. V).
$\mathrm{pH} 2$ in $\mathrm{M}$. longissimus dorsi $(P<0.01)$ and M. biceps femoris $(P<0.05)$ was higher during the warm season in the tropical climate than in the control environment whereas no difference was observed in $\mathrm{M}$. semispinalis. Exposure of the pigs to the tropical climate conditions induced a decrease in moisture loss of biceps femoris and semispinalis muscles $(P<0.05)$, as compared to the control environment (Tab. V).

Table V. The effect of tropical climate and season on meat quality and chemical composition of M. longissimus dorsi and M. semispinalis in growing pigs slaughtered at $90 \mathrm{~kg}$ live weight.

\begin{tabular}{|c|c|c|c|c|c|}
\hline & \multicolumn{3}{|c|}{ Environment } & \multirow[b]{3}{*}{ R.S.D. } & \multirow{3}{*}{$\begin{array}{l}\text { Significance }^{1} \\
\text { E }\end{array}$} \\
\hline & \multirow{2}{*}{$\begin{array}{l}\text { Control } \\
20{ }^{\circ} \mathrm{C} \\
75 \% \mathrm{RH}\end{array}$} & \multicolumn{2}{|c|}{ Tropical climate } & & \\
\hline & & $\begin{array}{l}\text { Cool season } \\
24.8 \pm 3.6^{\circ} \mathrm{C}\end{array}$ & $\begin{array}{l}\text { Warm season } \\
27.9 \pm 3.0^{\circ} \mathrm{C}\end{array}$ & & \\
\hline Meat quality & & & & & \\
\hline $\begin{array}{l}\text { M. longissimus dorsi } \\
\text { pH1 } \\
\text { pH2 } \\
\text { Moisture loss }(\%)^{2}\end{array}$ & $\begin{array}{l}6.21 \\
5.52^{\mathrm{a}} \\
21.4\end{array}$ & $\begin{array}{l}6.21 \\
5.60^{\mathrm{ab}} \\
21.4\end{array}$ & $\begin{array}{l}6.37 \\
5.71^{\mathrm{b}} \\
20.7\end{array}$ & $\begin{array}{l}0.20 \\
0.08 \\
2.8\end{array}$ & $\begin{array}{l}\mathrm{ns} \\
* * \\
\mathrm{~ns}\end{array}$ \\
\hline $\begin{array}{l}\text { M. biceps femoris } \\
\text { pH1 } \\
\text { pH2 } \\
\text { Moisture loss }(\%)\end{array}$ & $\begin{array}{c}6.05 \\
5.58^{\mathrm{a}} \\
24.8^{\mathrm{a}}\end{array}$ & $\begin{array}{l}6.06 \\
5.63^{\mathrm{ab}} \\
22.7^{\mathrm{ab}}\end{array}$ & $\begin{array}{c}6.17 \\
5.88^{\mathrm{b}} \\
21.4^{\mathrm{b}}\end{array}$ & $\begin{array}{l}0.20 \\
0.08 \\
3.2\end{array}$ & $\begin{array}{l}\mathrm{ns} \\
* \\
*\end{array}$ \\
\hline $\begin{array}{l}\text { M. semispinalis } \\
\text { pH1 } \\
\text { pH2 } \\
\text { Moisture loss }(\%)\end{array}$ & $\begin{array}{r}6.08 \\
5.84 \\
18.5^{\mathrm{a}}\end{array}$ & $\begin{array}{r}6.11 \\
5.86 \\
15.3^{\mathrm{b}}\end{array}$ & $\begin{array}{r}6.10 \\
5.83 \\
15.5^{\mathrm{b}}\end{array}$ & $\begin{array}{l}0.21 \\
0.15 \\
1.9\end{array}$ & $\begin{array}{l}\mathrm{ns} \\
\mathrm{ns} \\
*\end{array}$ \\
\hline $\begin{array}{l}\text { Chemical composition (\%) } \\
\text { M. longissimus dorsi }\end{array}$ & & & & & \\
\hline $\begin{array}{l}\text { Dry matter } \\
\text { Lipid } \\
\text { Protein }\end{array}$ & $\begin{array}{r}25.8 \\
1.8 \\
22.4\end{array}$ & $\begin{array}{r}26.2 \\
1.9 \\
23.0\end{array}$ & $\begin{array}{r}25.1 \\
1.9 \\
22.6\end{array}$ & $\begin{array}{l}1.6 \\
0.4 \\
1.4\end{array}$ & $\begin{array}{l}\text { ns } \\
\text { ns } \\
\text { ns }\end{array}$ \\
\hline $\begin{array}{l}\text { M. semispinalis } \\
\text { Dry matter } \\
\text { Lipid } \\
\text { Protein }\end{array}$ & $\begin{array}{c}25.4^{\mathrm{ab}} \\
5.9^{\mathrm{ab}} \\
18.2^{\mathrm{a}}\end{array}$ & $\begin{array}{r}27.4^{\mathrm{a}} \\
6.7^{\mathrm{a}} \\
19.4^{\mathrm{b}}\end{array}$ & $\begin{array}{r}23.1^{\mathrm{b}} \\
4.6^{\mathrm{b}} \\
16.0^{\mathrm{c}}\end{array}$ & $\begin{array}{l}2.4 \\
1.4 \\
1.1\end{array}$ & $\begin{array}{c}* \\
* \\
* * *\end{array}$ \\
\hline
\end{tabular}

E: effect of environment.

${ }^{1}$ ns: not significant; $* P<0.05 ; * * P<0.01 ; * * * P<0.001$

a, b, c Means that do not have a common superscript letter differ significantly.

pH1: pH 45 min post mortem; pH2: pH 24 h post mortem.

${ }^{2}$ Moisture loss was calculated as the weight of water lost in filter paper divided by the initial weight of fresh muscle samples and expressed as a percentage. 


\subsubsection{Muscle}

The lipid content of M. semispinalis was about three times higher than that of M. longissimus dorsi, averaging $5.7 \pm 1.4$ and $1.9 \pm 0.1 \%$, respectively $(P<0.001)$.
The dry matter, protein and lipid contents of M. longissimus dorsi was not altered by the environmental conditions (Tab. V). However, the environment had a mild influence on the fatty acid composition of lipids in M. longissimus dorsi (Tab. VI). In the

Table VI. The effect of the tropical climate and season on fatty acid composition of lipids in M. longissimus dorsi and M. semispinalis (as \% total fatty acids) in growing pigs slaughtered at $90 \mathrm{~kg}$ live weight.

\begin{tabular}{|c|c|c|c|c|c|}
\hline \multirow[b]{3}{*}{$\begin{array}{l}\text { Fatty acids } \\
(\%)\end{array}$} & \multicolumn{3}{|c|}{ Environment } & \multirow[b]{3}{*}{ R.S.D. } & \multirow{3}{*}{$\begin{array}{c}\text { Significance }^{1} \\
\text { E }\end{array}$} \\
\hline & \multirow{2}{*}{$\begin{array}{l}\text { Control } \\
20{ }^{\circ} \mathrm{C}, \\
75 \% \mathrm{RH}\end{array}$} & \multicolumn{2}{|c|}{ Tropical climate } & & \\
\hline & & $\begin{array}{l}\text { Cool season } \\
24.8 \pm 3.6^{\circ} \mathrm{C}\end{array}$ & $\begin{array}{l}\text { Warm season } \\
27.9 \pm 3.0^{\circ} \mathrm{C}\end{array}$ & & \\
\hline \multicolumn{6}{|l|}{ M. longissimus dorsi } \\
\hline C14:0 & 1.4 & 1.6 & 1.3 & 0.4 & ns \\
\hline C16:0 & 24.8 & 25.1 & 24.3 & 1.1 & ns \\
\hline C16:1 & $2.8^{\mathrm{a}}$ & $2.7^{\mathrm{a}}$ & $3.2^{\mathrm{b}}$ & 0.4 & $*$ \\
\hline C18:0 & $12.9^{\mathrm{ab}}$ & $13.4^{\mathrm{a}}$ & $12.3^{\mathrm{b}}$ & 0.6 & $*$ \\
\hline C18:1 & $41.7^{\mathrm{ab}}$ & $40.0^{\mathrm{a}}$ & $43.2^{\mathrm{b}}$ & 1.5 & $* *$ \\
\hline C18:2 & 13.1 & 13.6 & 12.1 & 1.8 & ns \\
\hline C18:3 & 0.34 & 0.33 & 0.29 & 0.11 & ns \\
\hline C20:0 & 0.10 & 0.10 & 0.15 & 0.05 & ns \\
\hline C20:1 & 0.46 & 0.47 & 0.66 & 0.19 & ns \\
\hline $\mathrm{C} 20: 4$ & 2.4 & 2.7 & 2.5 & 0.9 & ns \\
\hline$\sum$ monounsaturated & $44.9^{\mathrm{a}}$ & $43.1^{\mathrm{a}}$ & $47.1^{\mathrm{b}}$ & 1.6 & $* *$ \\
\hline $\begin{array}{l}\sum \text { polyunsaturated } \\
\text { Unsaturation }\end{array}$ & 15.8 & 16.6 & 14.9 & 2.1 & ns \\
\hline coefficient $^{2}(\%)$ & 1.24 & 1.25 & 1.22 & 0.04 & ns \\
\hline $\mathrm{P} / \mathrm{S}^{3}$ & 0.41 & 0.42 & 0.39 & 0.06 & ns \\
\hline \multicolumn{6}{|l|}{ M. semispinalis } \\
\hline C14:0 & 1.3 & 1.4 & 1.4 & 0.1 & ns \\
\hline C16:0 & 25.3 & 25.5 & 25.8 & 0.8 & ns \\
\hline C16:1 & $2.4 \mathrm{a}$ & $2.3^{\mathrm{a}}$ & $2.8^{\mathrm{b}}$ & 0.2 & $*$ \\
\hline C18:0 & 14.8 & 15.4 & 14.3 & 1.0 & ns \\
\hline C18:1 & $42.7^{\mathrm{a}}$ & $41.8^{\mathrm{a}}$ & $45.0^{\mathrm{b}}$ & 1.4 & $*$ \\
\hline C18:2 & $11.5^{\mathrm{a}}$ & $11.5^{\mathrm{a}}$ & $9.1^{\mathrm{b}}$ & 1.2 & $*$ \\
\hline C18:3 & $0.48^{\mathrm{a}}$ & $0.50^{\mathrm{a}}$ & $0.37^{\mathrm{b}}$ & 0.05 & $*$ \\
\hline C20:0 & 0.13 & 0.12 & 0.11 & 0.02 & ns \\
\hline C20:1 & 0.56 & 0.57 & 0.50 & 0.06 & ns \\
\hline $\mathrm{C} 20: 4$ & $0.83^{\mathrm{a}}$ & $0.91^{\mathrm{a}}$ & $0.62^{\mathrm{b}}$ & 0.16 & $*$ \\
\hline$\sum$ monounsaturated & $45.7^{\mathrm{a}}$ & $44.7^{\mathrm{a}}$ & $48.3^{\mathrm{b}}$ & 1.5 & $*$ \\
\hline $\begin{array}{l}\sum_{\text {Unsaturation }} \text { polyunsaturated } \\
\text { Uns }\end{array}$ & $12.8^{a}$ & $12.9^{a}$ & $10.1^{\mathrm{b}}$ & 1.4 & $*$ \\
\hline coefficient $^{2}(\%)$ & $1.22^{\mathrm{a}}$ & $1.22^{\mathrm{a}}$ & $1.17^{\mathrm{b}}$ & 0.02 & $*$ \\
\hline $\mathrm{P} / \mathrm{S}^{3}$ & $0.31^{\mathrm{a}}$ & $0.30^{\mathrm{a}}$ & $0.24^{\mathrm{b}}$ & 0.04 & $*$ \\
\hline
\end{tabular}

E: effect of environment.

${ }^{1}$ ns: not significant; $* P<0.05$; $* * P<0.01$.

a, b Means that do not have a common superscript letter differ significantly.

2,3 Unsaturation coefficient and P/S were calculated as indicated in Table IV. 
tropical climate, a rise in the percentage of C16:1 $(P<0.05)$ and C18:1 $(P<0.01)$ during the warm season was observed relative to the cool season, but it did not result in a significant change in the unsaturation coefficient.

Contrary to M. longissimus dorsi, the chemical composition of M. semispinalis was widely modified by the season in the tropical climate. Under the tropical climate, the dry matter content of M. semispinalis was 4.3 percentage units lower $(P<0.05)$ during the warm season than that observed during the cool season, as well as there being a decline in the protein $(P<0.001)$ and lipid $(P<0.05)$ contents $(\mathrm{Tab} . \mathrm{V})$. There was a concomitant increase in the proportion of monounsaturated fatty acids (C16:1 and C18:1) $(P<0.05)$ whereas polyunsaturated fatty acids $(\mathrm{C} 18: 2$ and $\mathrm{C} 18: 3)(P<0.05)$ were reduced (Tab. VI). In M. semispinalis, the polyunsaturated to saturated fatty acids ratio $(P<0.05)$ and the unsaturation coefficient $(P<0.05)$ were the lowest in the tropical climate during the warm season.

\section{DISCUSSION}

The comparison between the ambient temperatures observed during this trial and those recorded over 20 successive years using a weather station, showed that experimental conditions were representative of a tropical climate in the area. This climate is characterised by a high $\mathrm{RH}$, an average ambient temperature changing from about 24 to $28^{\circ} \mathrm{C}$ from one season to another and marked nocturnal variations in these two climatic components. The present results indicate that the changes in growth performance due to exposure to a tropical climate are concomitant to modifications in adipose tissue and muscle, but are not exactly the same as the variations due to constant high ambient temperature [18]. This can be related to the complexity of the tropical climate which does not quite mimic the effects of average ambient temperature probably due to the rather large nocturnal fluctuation in ambient temperature.

\subsection{Growth performance and carcass characteristics}

The reduced VFI in the tropical climate during the warm season is in good agreement with the well known negative relation between ambient temperature and VFI [24, 28]. When pigs are reared in semi-open-air conditions in temperate areas, an $8 \%$ decline in average daily gain has been shown in 35 to $90 \mathrm{~kg}$ animals during the summer as compared to the winter $[21,33]$. This finding agrees with present data indicating a similar $9 \%$ reduction in growth rate during the warm season in the tropics, as compared to the cool one. It is well known that in pigs fed ad libitum, the increase in ambient temperature induces a reduction in carcass fatness $[17,23,25,31]$, when the animals are given a protein balanced diet $[19,32]$. These findings are consistent with present data obtained in the tropical climate showing a reduction in backfat thickness whatever the season and the lowest fat percentage during the warm season.

\subsection{Adipose tissue composition}

In the tropical climate, the variation between the lipid contents of the two layers of backfat was likely due to the difference in the lipid metabolism of those layers, as previously reported in the study of Camara et al. [5]. This study shows that the outer layer of backfat is richer in lipids in 20 to $50 \mathrm{~kg}$ Large White pigs whereas it is poorer in heavier animals, the shift occurring at about $100 \mathrm{~kg}$ live weight. Our present results demonstrate that the exposure of pigs to tropical conditions modifies both the lipid content and the concentration in various fatty acids of the subcutaneous fat whereas only the lipid and linolenic contents of leaf fat are altered. Such differences in tissue susceptibilities to the environment have 
previously been reported [18] and could be related to the actual temperature of the tissue [20].

The shift of fat distribution from external sites towards internal sites previously found during the warm season in tropical climates [29], is connected to a reduction in both the weight of backfat and in the lipid content of its outer layer. Similar changes have also been recorded at a constant high ambient temperature of $31.5^{\circ} \mathrm{C}$ in $30 \mathrm{~kg}$ pigs [28]. The reduction in feed intake has previously been described to induce a lower weight and lipid content of backfat $[1,37]$. However, according to Lebret et al. [16], the modifications in the chemical composition of backfat with changes in temperature and season are not necessarily related to the concomitant variations in VFI. The shift in body fat distribution was therefore assumed to reflect an adaptation to warm conditions since heat loss is promoted through reduced thermal insulation [15]. Further investigations are still needed to describe the mechanisms by which ambient temperature alters body fat distribution.

Irrespective of the influence of the environment, the level of $\mathrm{C} 18: 2$ in backfat was much higher than the recommended $12-15 \%$ [36]. The high level of C18:2 in backfat was likely due to feed composition, since it is well known that linoleic acid concentration in carcass fat is highly correlated to that contained in the diet $[7,38]$. In the present trial, the two diets given to the pigs contained respectively 18.5 and $19.9 \mathrm{~g}$ $\mathrm{C} 18: 2 \cdot \mathrm{kg}^{-1}$, whereas the recommended level is about 10 to $12 \mathrm{~g} \cdot \mathrm{kg}^{-1}$. The decrease in C18:1 and C20:1 together with the increase in $\mathrm{C} 18: 2$ and $\mathrm{C} 18: 3$ in the backfat of pigs reared in the tropical climate have previously been shown at a constant high temperature of $28^{\circ} \mathrm{C}$ [18]. The reduced VFI in the tropical climate accounts for the increase in $\mathrm{C} 18: 2$ and $\mathrm{C} 18: 3$ in backfat, since the negative correlation between the level of feed intake and the C18:2 and C18:3 contents of fat has been well described $[37,38]$.
The higher unsaturation coefficient of external fat in warm conditions in the tropical climate, is consistent with the findings of Lebret et al. [16]. The latter have shown that, in temperate areas, the degree of unsaturation of backfat is higher in animals fed ad libitum during the summer at an average temperature of $26{ }^{\circ} \mathrm{C}$ than in those raised during the winter at an average temperature of $18.3^{\circ} \mathrm{C}$. This is considered as favourable, as far as the nutritional value is concerned. However, Lebret et al. [16] indicated that the summer has positive effets not only on the higher unsaturation of subcutaneous adipose tissue but also on its increased degree of firmness, in relation to higher levels of $\mathrm{C} 16: 0$ and $\mathrm{C} 18: 0$. In the present trial, the $\mathrm{C} 16: 0$ and $\mathrm{C} 18: 0$ contents in backfat were not modified by the environment suggesting that backfat firmness did not change. However, further investigations are needed to evaluate the effects of warm and humid conditions on the actual backfat firmness and therefore its ability to be processed.

\subsection{Muscle composition and lean meat quality}

The higher lipid content of red skeletal muscle, such as M. semispinalis, compared to white muscle, such as M. longissimus dorsi, is well documented [4]. The current finding of a decrease in the lipid content of M. semispinalis during the warm season in the tropical climate whereas M. longissimus dorsi is not affected, is consistent with previous reports. Environmental temperature has been shown to modify chemical composition, fibre types and metabolic activities in red muscle while no or a minor change has been observed in white muscle $[18,27]$.

It is known that polyunsaturated to saturated fatty acids ratio is one of the most reliable markers of nutritional value of lean meat [38]. The average values of the polyunsaturated to saturated fatty acids ratio are close to the recommended 0.45 value in $\mathrm{M}$. longissimus 
dorsi and lower in M. semispinalis. In the present study, environmental conditions had no effect on the polyunsaturated to satured fatty acids ratio in M. longissimus dorsi. Similar results were observed by Gandemer et al. [13] when comparing pigs raised indoors or outdoors.

Since the average ambient temperature in tropical climate is higher than in the control environment, higher values of $\mathrm{pH} 2$ are measured in the longissimus dorsi and biceps femoris muscles. Previous studies on the effect of ambient temperature on $\mathrm{pH} 2$ are controversial. Lefaucheur et al. [18] described an increase in $\mathrm{pH} 2$ in the longissimus dorsi muscle at a constant ambient temperature of $28^{\circ} \mathrm{C}$ as compared to $12^{\circ} \mathrm{C}$ which is in good agreement with the present data. However, in temperate areas, Lebret et al. [16] found no change in $\mathrm{pH} 2$ in the summer at an average temperature of $26{ }^{\circ} \mathrm{C}$ as compared to the winter at an average $18.3{ }^{\circ} \mathrm{C}$. The higher values of $\mathrm{pH} 2$ in the tropical climate are not closely related to moisture loss, as previously reported [18].

Altogether, the results of this study suggest that the changes in tissue composition and pork quality induced by a tropical climate may be favourable. The higher ultimate $\mathrm{pH}$ and the lower moisture loss found during the warm season may reflect the improvement in the technological quality of lean meat. The reduced lipid content of the outer layer of backfat and the higher degree of unsaturation of entire backfat might suggest a better nutritional quality of fat. However, the chemical composition of M. longissimus dorsi hardly changed. The suggested favourable influence of high temperature in the tropical climate on meat quality had previously been demonstrated at a constant $28{ }^{\circ} \mathrm{C}$ [18]. This should be confirmed by further information. However, in the tropics, the consumers' preference for locally produced pork, as compared to imported meat, might also be due to the use of local breeds. In the Caribbean, better technological and sensory qualities of meat have been suggested in local Creole pigs compared to Large White animals [9] but this still has to be clearly demonstrated. We thus plan to study the interactive effects of climate and breed, i.e. Large White vs. Creole, on meat properties and tissue composition in the tropics.

\section{ACKNOWLEDGMENTS}

The authors gratefully acknowledge G. Gravillon and A. Cléonis for high skills in carrying out the experiment as well as P. Marival, J. Belfort, A. Bructer, A. André, B. Calif, D. Feuillet and L. Philibert for technical assistance in the slaughtering of pigs and chemical analyses. Particular thanks are owed to A. Mounier for performing fatty acid composition of lipids and for his precious advice in lipid analyses.

\section{REFERENCES}

[1] Affentranger P., Gerwig C., Seewer G.J.F., Schwörer D., Künzi N., Growth and carcass characteristics as well as meat and fat quality of three types of pigs under different feeding regimens, Livest. Prod. Sci. 45 (1996) 187-196.

[2] Barton-Gade P.A., Meat and fat quality in boars, castrates and gilts, Livest. Prod. Sci. 16 (1987) 187-196.

[3] Becker B.A., Knight C.D., Buonomo F.C., Jesse G.W., Hedrick H.B., Baile C.A., Effect of a hot environment on performance, carcass characteristics, and blood hormones and metabolites of pigs treated with porcine somatotropin, J. Anim. Sci. 70 (1992) 2732-2740.

[4] Bout J., Girard J.P., Lipides et qualités du tissu musculaire, facteurs de variation, Journ. Rech. Porcine Fr. 20 (1988) 271-278.

[5] Camara M., Mourot J., Chérot P., Mounier A., Évolution de la composition lipidique de la bardière en fonction de l'âge. Comparaison entre le porc Large White et le porc Meishan, Journ. Rech. Porcine Fr. 26 (1994) 163-168.

[6] Cheah K.S., Dauncey M.J., Cheah A.M., Ingram D.L., Influence of environmental temperature and energy intake on porcine skeletal muscle mitochondria, Comp. Biochem. Physiol. 82 B (1985) 287-292.

[7] Courboulay V., Mourot J., Use of diets rich in linoleic acid on pork fat quality: effect of the duration of supply and clearance rate estimation of this fatty acid, 46th Annual meeting of the EAAP, Prague, September 4-7, 1995. 
[8] Desmoulin B., Ecolan P., Bonneau M., Estimation de la composition tissulaire des carcasses de porcs, INRA Prod. Anim. 1 (1988) 59-64.

[9] Deprés E., Tamisier F., Naves M., Rinaldo D. Comparaison de porcs Créole et Large White pour les performances de croissance et la qualité de la viande en fonction de l'âge à l'abattage, Journ. Rech. Porcine Fr. 24 (1992) 17-24.

[10] Ellis M., Webb A.J., Avery P.J., Brown I., The influence of terminal sire genotype, sex, slaughter weight, feeding regime and slaughter-house on growth performance and carcass and meat quality in pigs and on the organoleptic properties of fresh pork, Anim. Sci. 62 (1996) 521-530.

[11] Ferguson N.S., Gous R.M., The influence of heat production on voluntary feed intake in growing pigs given protein-deficient diets, Anim Sci. 64 (1997) 365-378

[12] Folch J., Lee M., Stanley G.H.S., A simple method for the isolation and purification of total lipids from animal tissue, J. Biol. Chem. 226 (1957) 497-509.

[13] Gandemer G., Pichou D., Bouguennec B., Caritez J.C., Berge Ph., Briand E., Legault C., Influence du système d'élevage et du génotype sur la composition chimique et les qualités organoleptiques du muscle Long dorsal chez le porc, Journ. Rech. Porcine Fr. 22 (1990) 101-110.

[14] Goutefongea R., Comparaisons de différentes méthodes de mesure du pouvoir de rétention d'eau de la viande de porc. Liaison avec le $\mathrm{pH}$, Ann. Zootech. 12 (1963) 125-132.

[15] Katsumata M., Kaji Y., Saitoh M., Growth and carcass fatness responses of finishing pigs to dietary fat supplementation at a high ambien temperature, Anim. Sci. 62 (1996) 591-598.

[16] Lebret B., Massabie P., Juin H., Mourot J., Clochefert N., Mounier A., Chevillon P., Bouyssière M., Le Denmat M., Influence des conditions d'élevage sur les performances de croissance du porc et la qualité des viandes. 2. Caractéristiques du muscle et du tissu adipeux et qualités technologiques et organoleptiques du jambon sel-sec, Journ. Rech. Porcine Fr. 30 (1998) 43-50.

[17] Le Dividich J., Noblet J., Herpin P., van Milgen J., Quiniou N., Thermoregulation, in: Wiseman J., Varley M.A., Chadwick J.P. (Eds.), Progres in pig science, Nothingham University Press, 1998, pp. 229-263.

[18] Lefaucheur L., Le Dividich J., Mourot J., Monin G., Ecolan P., Krauss D., Influence of environmental temperature on growth, muscle and adipose tissue metabolism and meat quality in swine, J. Anim. Sci. 69 (1991) 2844-2854.

[19] Lopez J., Goodband R.D., Allee G.L., Jesse G.W., Nelssen J.L., Tokach M.D., Spiers D., Becker B.A., The effect of diets formulated on an ideal protein basis on growth performance, carcass characteristics, and thermal balance of finishing gilts housed in a hot, diurnal environment, J. Anim. Sci. 72 (1994) 367-379.
[20] MacGrath W.S., Van der Noot G.W., Gilbreath R.L., Fisher H., Influence of environmental temperature and dietary fat on backfat composition of swine, J. Nutr. 96 (1968) 461-466.

[21] Massabie P., Granier R., Le Dividich J., Chevillon P., Bouyssière M., Lebret B., Le Denmat M., Influence des conditions d'élevage sur les performances de croissance du porc et la qualité des viandes. 1. Effet sur les performances zootechniques et la qualité de la carcasse, Journ. Rech. Porcine Fr. 30 (1998) 37-41.

[22] Morrison W.R., Smith L.M., Preparation of fatty acid methyl esters and dimethylacetals from lipids with boron fluorid-methanol, J. Lipid Res. 5 (1964) 600-608.

[23] Myer R.O., Bucklin R.A., Fialho F.B., Effects of increased dietary lysine (protein) levels on performance and carcass characteristics of growing-finishing pigs reared in a hot, humid environment, Trans. ASAE 41 (1998) 447-452.

[24] Nienaber J.A., LeRoy Hahn G., Heat production and feed intake of ad libitum feed growing swine as affected by temperature, ASAE Summer Meeting, June 27-30, 1982, Saint'Joseph, Michigan, paper 82-4065.

[25] Nienaber J.A., LeRoy Hahn G., Performance of growing-finishing pigs in response to the thermal environment, ASAE Mid-Central meeting, March 16, 1983, Saint'Joseph, Missouri, paper MCR 83-137.

[26] Ollivier L., L'épreuve de la descendance chez le porc Large White français de 1953 à 1966. I. Analyse de la variation, Ann. Génét. Sél. Anim. 2 (1970) 311-319.

[27] Rinaldo D., Le Dividich J., Effects of warm exposure on adipose tissue and muscle metabolism in growing pigs, Comp. Biochem. Physiol. 100 A (1991) 995-1002.

[28] Rinaldo D., Le Dividich J., Assessment of optimal temperature for performance and chemical body composition of growing pigs, Livest. Prod. Sci. 29 (1991) 61-75.

[29] Rinaldo D., Le Dividich J., Noblet J., Adverse effects of tropical climate on voluntary feed intake and performance of growing pigs, Livest. Prod. Sci. 66 (2000) 223-234.

[30] S.A.S., 1994. S.A.S./STAT User's Guide: statistics. S.A.S., Inst., Inc., Cary, North Caroline.

[31] Stahly T.S., Cromwell G.L., Effect of environmental temperature and dietary fat supplementation on the performance and carcass characteristics of growing and finishing swine, J. Anim. Sci. 49 (1979) 1478-1488.

[32] Stahly T.S., Cromwell G.L., Aviotti P., The effect of environmental temperature and dietary lysine source and level on the performance and carcass characteristics of growing swine, J. Anim. Sci. 49 (1979) 1242-1251. 
[33] Stahly T.S., Cromwell G.L., Overfield J.R Interactive effects of season of year and dietary fat supplementation, lysine source and lysine level on the performance of swine, J. Anim. Sci. 53 (1981) 1269-1277.

[34] Touraille C., Monin G., Legault C., Eating quality of meat from European $\times$ Chinese crossbred pigs, Meat Sci. 25 (1989) 177-186.

[35] Van Soest P.J., Robertson J.B., Lewis B.A., in: Symposium: Carbohydrate methodology, metabolism and nutritional implications in dairy cattle. Methods for dietary fiber, neutral detergent fiber and nonstarch polysaccharides in relation to animal nutrition, J. Dairy Sci. 74 (1991) 3583-3597.

[36] Wood J.D., Fat deposition and the quality of fat tissue in meat animals, Fats in Animal Nutrition, in: Wiseman J. (Ed.), London, Butterworths, 1984, pp. 407-435.

[37] Wood J.D., Buxton P.J., Whittington F.M., Enser M., The chemical composition of fat tissues in the pig: effects of castration and feeding treatment, Livest. Prod. Sci. 15 (1986) 73-82.

[38] Wood J.D., Enser M., Factors influencing fatty acids in meat and the role of antioxidants in improving meat quality, Brit. J. Nutr. 78 (Suppl. 1) (1997) S49-S60. 